Walter Costa Porto, advogado, pós-graduado ent sociologia do direjto pelo ICH/UFPE, editor da revista "Arquivos" do $\mathrm{M}\rfloor \mathrm{e}$ presidente da Fundação Petrônio Portela.

\title{
Comentários sobre a exposição de Frank Moss
}

Desejo, apenas, trazer duas breves considerações às palavras do Senador Moss - pela exiguidade de meu tempo e pelo fato de que sua palestra, brilhante, não pode ser refutada ou, de qualquer modo, complementada

A primeira é a constatação de que convivemos tão familiarmente com as instituições políticas, elas nos cercam desde a infância, nos rodeiam, de tal modo que nunca indagamos sobre seu sentido, sua importância, sua natureza intima.

Mesmo os que residem em Brasilia, os que atravessam muitas vezes a Praça dos Três Poderes, essa singular Praça dos Três Poderes, mesmo eles nunca se detêm para uma reflexão sobre esse mecanismo tão sabiamente utilizado pelos revolucionários americanos do final do século XVIII: que levou a que se contrapusessem Executivo. Legislativo e Judiciário, com a diretriz expressa de que nem um homem isolado, nem qualquer grupo pudessem ter demasiado poder.

Não foi uma invenção americana;
Aristóteles, há 23 séculos passados, já fala. va em separação de funçōes, a mais importante para ele sendo a legislativa; Políbio, esse antecipador fantástico do século I A.C. mostrava "poderes que se contrabalançavam". "poderes que se desajustavam" - o dos Cônsules, o do Senado e a do povo, pelos seus Tribunos; e Montesquieu, afinal, filtrando a experiência inglesa, reservou páginas famosas de seu "Espirito das Leis" à tripartição dos poderes.

Completando, em um solo novo, o longo intento inglês de limitação do poder real, os "pais fundadores" da nação americana enfatizaram um ângulo novo، a que desejo resumir minha participação aqui: a do estabelecimento, nas relações de governo, de um "equilíbrio precário", porém fundamental à defesa do cidadão contra a possibilidade de um Estado opressor.

Uma das críticas à separação de poderes é que ela poderia levar, pelo atrito entre os ramos do Legislativo, do Executivo e do Judiciário, a uma inação de governo.

Essa crítica é rebatida por Montesquieu 
com a alegaçāo de que o governo, de qualquer modo se moverá, pela natureza das coisas.

Mas essa acusacão é melhor respondida por aqueles que idealizaram a Constituicão de 1789: se a tripartição de poderes e de funções levar a um impasse, a uma inação, aceite-se esse ônus como um mal menor; pior, muito pior, seria que um excessivo poder, que demasiado arbitrío fosse dado a um homem ou a um grupo.

Completa-se, aí, um ciclo que se inicia com Aristóteles; mantém-se o mecanismo de divisão mas outros são seus fundamentos; o que se separava pela natureza das funçōes, se separa, agora, sobretudo, em busca de garantias para o cidadão. Divide-se o poder do Estado, divide-se o Leviatã, mas para limitá-lo

A segunda ordem de considerações que desejo tecer aqui diz respeito à transposição desse esquema de tripartição de poderes para o caso brasileiro.

Um senador de nosso partido governista, designado para uma das muitas comissões que estudaria alterações em nossa legislação eleitoral, há pouco tempo, disse à imprensa que "não adiantaria transplantar para o Brasil a realidade dos Estados Unidos, da França e de outros países"

Qualquer leitor um pouco familiarizado com a história de nossas instituições arrolarỉa, porém, sem esforço, muitos exemplos desses transplantes, tais como o federalismo. o bicameralismo, o bipartidarismo recente, a representação proporcional, o sistema de quociente eleitoral e, até mesmo, o regime democrático, uns a vingar notavelmente em nosso solo, outros quase a fenecer em razão dos rigores do clima.

Mas cabe perguntar se no campo das instituições e das realidades políticas as inovaçoes serão mesmo possiveis, a originalidade não se constituindo, aí, em verdade. senão em adaptações do antigo, em variações sobre experiências vitoriosas em outros meridianos.

Elucidativo é, entre nós, o caso do Poder Moderador. A única Constituiçâo a adotá-lo tería sido, no Ocidente, a nossa Carta de 1824

Um professor da Faculdade de Direito do Recife, Braz Florentino Henrique de Souza, indagava, contudo, em livro de 1864 se seria o Poder Moderador uma dessas "criaçōes fantásticas, puro devaneio da imaginação ensandecida de inexpertos legisladores?"

Não, pois toi a Benjamin Constant, orientado pelo Conde de Clermont Tonerre. a quem coube a honra de caracterizar pela primeira vez, aquele "poder supremo". A originalidade, no Império brasileiro, seria a União, em um só titular, do Poder Executivo e do Poder Moderador, que Benjamim Constant desejava "neutro".

Temos, então, que no campo da organização dos Estados não se devem procurar novidades; mais conveniente será que se imitem mesmo os métodos e processos que a rotina mostrou acertados. E o mal estaria somente no transplante indevido, na aplica ção imprópria, a realidades outras, de instrumental que se mostrasse, assim, inade quado.

Os exemplos cotidianos do Brasil recente mostram que não assimilamos verdadeiramente o exemplo americano no campo dá separação de poderes.

A surpresa, que os jornais traduziram, há pouco, quanto à reação de nosso Congresso a Decretos-leis do Executivo, e a sofrida e tumultuada tramitação desses textos indicam que o longo oficialismo, que marcou 
nossa formação como país, ainda reluta em aceitar os diferentes ramos do poder como efetivos co-participantes de governo

Longo oficialismo que levou à afirmação de Alceu Amoroso Lima de que "nosso país se formou às avessas, começando pelo fim, tendo Coroa antes de ter povo: parlamentismo, antes de ter eleiçöes; escolas superiores, antes de ter alfabetismo: bancos antes de ter economias; conceito exterior. antes de ter consciência interna".

Estado de mais, sociedade de menos é o diagnóstico final que não se coaduna com a receita de Montesquieu ou de Madinson.

Um segundo item, entre tantos, que parece corroborar a onipresença do Estado entre nós e a falta de adequada canalização das aspirações da sociedade, é nossa insistência em negar, nossa teimosia em desconhecer a ação dos grupos de interesse ou de pressão.

Um mero artigo do Regimento da Câmara dos Deputados - o artigo 60, que permite o credenciamento de entidades - em todo o nosso direito positivo e uma bibliografía paupérrima - somente existindo um livro de Leda Boechat Rodrigues - atestam isso.

É bem verdade que esses grupos receberam, inicialmente, a mais severa reprovação dos "pais fundadores" da democracia americana. Mas, a rigor, o modelo de 1789 não só tolera, ao lado dos ramos formais de governo, a atividade informal desses segmentos sociais: os grupos de interesse ou pressão findaram por se constituir, ali, em privilegiados protagonistas da cena política. chegando-se, com evidente exagero, a se ver os governantes como simples árbitros do conflito entre os grupos.

A ação política exercida, nesta última década brasileira, por grupos como a Igreja, os sindicatos, a Ordem dos Advogados, mostra um pouco da inconformidade de nossa sociedade, procurando corrigír o modelo, mal transplantado ou, pelo menos, não transplantado em toda sua inteireza.

Essas as minhas despretenciosas anotaçöes, ao ouvir o Senador Moss falar de realidades para nós tão próximas e das quais, em alguns aspectos, tanto nos distanciamos. 